\title{
INTRASPECIFIC VARIATION IN THE INTERNAL TRANSCRIBED SPACER (ITS) REGION OF GREEN PEACH APHID MYZUS PERSICAE [(SULZER) (HEMIPTERA: APHIDIDAE)] UNDER ELEVATED ATMOSPHERIC $\mathrm{CO}_{2}$ PRESSURE
}

\author{
KARACAOĞLU, M. \\ Department of Plant Protection, Faculty of Agriculture, Malatya Turgut Ozal University, \\ Battalgazi/Malatya, Turkey \\ e-mail:mehmet.karacaoglu@ozal.edu.tr
}

(Received $9^{\text {th }}$ Feb 2021; accepted $16^{\text {th }}$ Apr 2021)

\begin{abstract}
The continuously increasing concentrations of atmospheric $\mathrm{CO}_{2}$ is predicted to affect biological processes at many levels of organisms. Yet, no study exists in the literature attempting to describe that the elevated atmospheric $\mathrm{CO}_{2}\left(\mathrm{eCO}_{2}\right)$ concentration may cause an evolutionary response on nucleotide sequences of ribosomal DNA of Myzus persicae [(Sulzer) (Hemiptera: Aphididae)]. Here, we provide a preliminary study to understand how the insect ribosomal DNA sequences are influenced under the elevated $\mathrm{CO}_{2}$ levels after several generations. Four $M$. persicae populations were established for 35 days under ambient $\mathrm{CO}_{2}\left(\mathrm{a} \mathrm{CO}_{2}\right)(400 \mathrm{ppm})$, e $\mathrm{CO}_{2}(600 \mathrm{ppm})$, e $\mathrm{CO}_{2}(800 \mathrm{ppm})$ and e $\mathrm{CO}_{2}(1000 \mathrm{ppm})$ at $29^{\circ} \mathrm{C}$ in moisture-controlled greenhouse chambers. Intraspecific variation of $M$. periscae was assessed by the sequencing and analyzing the internal transcribed spacer (ITS) region of Myzus persicae (Sulzer) under elevated atmospheric $\mathrm{CO}_{2}$ pressure. Based on our results, the phylogenetic analysis of ITS sequences differentiated the individuals grown at $800 \mathrm{ppm} \mathrm{CO}$ level. The alignment of ITS sequences of all specimens revealed several single-nucleotide substitutions on the nucleotide sequence of $M$. persicae samples grown at $800 \mathrm{ppm} \mathrm{CO}_{2}$ level. Overall results show that the elevated atmospheric $\mathrm{CO}_{2}$ levels could be a powerful evolutionary force than expected on $M$. persicae reared on eggplants.
\end{abstract}

Keywords: evolution, atmospheric $\mathrm{CO}_{2}$, alignment, intraspecific variation, nucleotide comparison

\section{Introduction}

Species of the Aphididae (Hemiptera) family species are found almost everywhere in the world, but these pests are more common in temperate regions than in the tropics. It has been reported that there are approximately 5000 species belonging to the Aphididae family in the world and 1600 species in Europe (Nieto Nafria et al., 2013; Blackman and Eastop, 2020). Considering aphids in Turkey, the number of species identified is reported to be 558 (Akyürek et al., 2019; Özdemir, 2020). Aphids are among the most significant pests in agricultural areas around the world. Myzus persicae Sulz. (Hemiptera: Aphididae) causes serious damage both in cover crop and the open field (Blackman and Eastop, 2006; Van Emden and Harrington, 2017). Aphids are generally considered polyphagous pests. Among them M. persicae feed on phloem tissue of plants (Pollard, 1973). As a result of feeding, the growth of the plant may stunt, produce plant galls, cause deformation of leaves, buds, and flowers and transmit plant virus diseases. M. persicae produces large amounts of a sugary liquid waste called "honeydew", and as a result of this secreted substance, saprophyte fungi can grow on honeydew that accumulate on leaves resulting in a decrease in the plant's photosynthesis (Lodos, 1982). This pest completes its life cycle in a short time when there are suitable climate conditions and continues its life throughout the season. Temperature and humidity play an important role in its development. 
M. persicae alone is reported to carry more than 150 plant virus diseases from different crops, including vegetables belonging to the Solanaceae family (Sharma et al., 2008).

Atmospheric $\mathrm{CO}_{2}$ has increased from about $280 \mathrm{ppm}$ to $400 \mathrm{ppm}$ since the Industrial Revolution in the mid-1700s (Bonan and Doney, 2018). In the inter-country climate panel held in 2014, it was reported that the atmospheric $\mathrm{CO}_{2}$ rate will increase between approximately 750 and $1300 \mathrm{ppm}$ by the year 2100 (IPCC, 2014). The increase in the $\mathrm{CO}_{2}$ ratio in the atmosphere in the next century will cause a decrease in the nutrient content in the host of many insect species, thus, it is expected that both larval development time and mortality rate will increase (Carlos and Trumble, 1998). Whether these changes will affect insects' feeding behavior, biology, host preferences, adaptation to climatic conditions and genetics is not clearly known. In the context of climate change, the impact of increased $\mathrm{CO}_{2}$ on insect species has become a major issue over the last three decades. Elevated $\mathrm{CO}_{2}$ levels may modify the insect behavior for feeding, but precise effects on insect genetics are poorly known. There have been many studies on the effects of enhanced $\mathrm{CO}_{2}$ on behavior of insect species (Stiling et al., 2002; Chen et al., 2007; Sudderth and Sudderth, 2014) however, there has been no investigation of the effects of elevated $\mathrm{CO}_{2}$ levels on intraspecific variation. The purpose of the study was to obtain some initial data regarding the possible effects of ambient and elevated $\mathrm{CO}_{2}$ levels on intraspecific variation on one example of a species (Myzus persicae) using the internal transcribed spacers of the ribosomal DNA (ITS rDNA) region.

\section{Materials and Methods}

\section{Source of green peach aphid and eggplants}

The colonies of green peach aphids trapped in the eggplant fields. Once aphids were identified, they were maintained in the temperature controlled growing chamber on the same species (Solanum melongena L. cv. Pala-49) at $14 \mathrm{~h}$ day length alternating at temperature of regimes $\left(29 / 19 \pm 1^{\circ} \mathrm{C}\right)$ under constant relative humidity $(60 \pm 10 \% \mathrm{RH}$ with 14:10 h L:D photoperiod at 8-10 klux light intensity photoperiod conditions). The aphids were sourced from the colony cultured on these plants. The eggplants (Solanum melongena L. cv. Pala-49) were then transferred to a temperature, humidity and $\mathrm{CO}_{2}$-controlled greenhouse at the Malatya Turgut Ozal University to provide plants for the experiments. A separate concentration of carbon dioxide level was applied in each compartment of the greenhouse including ambient (400 ppm) and elevated $600 \mathrm{ppm}$, $800 \mathrm{ppm}$, and $1000 \mathrm{ppm} \mathrm{CO}_{2}$ levels, consisting of four compartments.

\section{Extraction of genomic DNA from the green peach aphid}

Genomic DNA of single aphid was simply and effectively extracted at room temperature using DNeasy ${ }^{\circledR}$ Blood \& Tissue Kit (Qiagen, Germany). Seventeen specimens of $M$. persicae were collected from eggplants grown at ambient (400 ppm) and elevated $(600,800,1000 \mathrm{ppm}) \mathrm{CO}_{2}$ levels. The four samples of $M$. persicae from ambient $\mathrm{CO}_{2}$ level (400 ppm) were served as controls (Table 1). In order to eliminate the external microbial contaminants, the aphid samples were rinsed in $70 \%$ ethanol for $5 \mathrm{~min}$ and then rinsed four times with sterilized water to eliminate the external microbial contaminants. The whole body of an adult aphid was used to purify total genomic DNA (Table 1). All DNA preparations were stored at $-20^{\circ} \mathrm{C}$ until use. 
Table 1. Characteristics of aphid samples used in this study grown under ambient and elevated $\mathrm{CO}_{2}$ levels

\begin{tabular}{c|c|c|c|c|c|c}
\hline $\begin{array}{c}\text { Number of } \\
\text { rooms }\end{array}$ & $\mathbf{C O}_{2}$ level & $\begin{array}{c}\text { Number of } \\
\text { individuals } \\
\text { produced }\end{array}$ & $\begin{array}{c}\text { Number of } \\
\text { samples } \\
\text { sequenced }\end{array}$ & $\begin{array}{c}\text { Number of } \\
\text { generations }\end{array}$ & $\begin{array}{c}\text { Temperature } \\
\text { of each room }\end{array}$ & $\begin{array}{c}\text { After the third } \\
\text { generation duration } \\
\text { of rearing (day) }\end{array}$ \\
\hline $1^{\text {st }}$ room & $400 \mathrm{ppm}$ & 150 & 4 & 4 & $29 / 19^{*}$ & 35 \\
$2^{\text {nd }}$ room & $600 \mathrm{ppm}$ & 180 & 5 & 4 & $29 / 19$ & 35 \\
$3^{\text {rd }}$ room & $800 \mathrm{ppm}$ & 130 & 4 & 4 & $29 / 19$ & 35 \\
$4^{\text {th }}$ room & $1000 \mathrm{ppm}$ & 140 & 4 & 4 & $29 / 19$ & 35 \\
\hline
\end{tabular}

${ }^{*}$ At $14 \mathrm{~h}$ day length at temperature of $29 / 19^{\circ} \mathrm{C}$ (L:D) photoperiod at 8-10 klux light intensity

\section{Elevated $\mathrm{CO}_{2}$ conditions and experimental design}

Five adult aphids maintained in the growing chamber were removed from their host plant and placed on young eggplant leaves grown at ambient (400 ppm) and elevated $600 \mathrm{ppm}, 800 \mathrm{ppm}$ and $1000 \mathrm{ppm}$ levels of $\mathrm{CO}_{2}$ in the green house. The trials were carried out at four-room temperature, humidity and $\mathrm{CO}_{2}$ controlled greenhouse facility located at Malatya Turgut Ozal University. Each had alternating $\left(29 / 19 \pm 1^{\circ} \mathrm{C}\right)$ temperature regimes under constant relative humidity and photoperiod conditions $(60 \pm 10 \% \mathrm{RH}$ with $14: 10 \mathrm{~h}$ L:D photoperiod) at 8-10 klux light intensity. M. persicae stock culture was established on the eggplant plant in each $\mathrm{CO}_{2}$ level room. Four young eggplant plants were placed in each room and five $M$. persicae individuals were transferred on each plant. The aphid samples were taken from the individuals grown in each room, after 4 generations. Individuals taken from each climate room were stored in sample bags at $-80^{\circ} \mathrm{C}$, and total DNA isolation was made from these samples. Genomic DNA isolation was performed from a single individual.

\section{PCR amplification of 16S rRNA and sequencing}

An approximately 730 bp DNA fragment of ITS region of nuclear ribosomal RNA (nrRNA) gene containing ITS1, 5.8S and ITS2 was amplified by polymerase chain reaction (PCR) with the primers (ITS4:5'-TCCTCCGCTTATTGATATGC-3' and ITS5: 5'-GGAAGTAAAAGTCGTAACAAGG-3') (White et al., 1990) (Figure 1). The PCR mixture consisted of $5 \mu \mathrm{L}$ of $10 \times$ reaction buffer $(200$ mMTris $-\mathrm{HCl} \mathrm{pH}: 8.4$, $500 \mathrm{mMKCl}), 2 \mu \mathrm{L}$ of genomic DNA, $1 \mu \mathrm{L}$ of dNTPs $\left(10 \mathrm{mM}\right.$ each), $3 \mu \mathrm{L}$ of $\mathrm{MgCl}_{2}$ ( $25 \mathrm{mM}), 1 \mu \mathrm{L}$ of each primer (100 pmol), $0.4 \mu \mathrm{L}$ of DNA polymerase, and $36.6 \mu \mathrm{L}$ of DNase free sterile water. PCR amplification was performed using the following thermocycling program: a 2 min initial denaturation at $94^{\circ} \mathrm{C}$, followed by 36 cycles of $94^{\circ} \mathrm{C}$ for $1 \mathrm{~min}$, annealing at $55^{\circ} \mathrm{C}$ for $1 \mathrm{~min}$ and an extension of $72^{\circ} \mathrm{C}$ for $2 \mathrm{~min}$, and a final extension of $72^{\circ} \mathrm{C}$ for $10 \mathrm{~min}$. The PCR amplified DNA fragments were separated on $2 \%$ agarose gel containing fluorescent dye and recovered by agarose gel extraction kit (Bioline, Germany). A total of 17 nuclear ribosomal DNA fragments of $M$. persicae samples, originated from the same population and reared at four levels of $\mathrm{CO}_{2}$, were sequenced after completing their $4^{\text {th }}$ generations in growing chamber. All the sequences studied in this study are deposited in GenBank database under the accession numbers given in Table 2. 


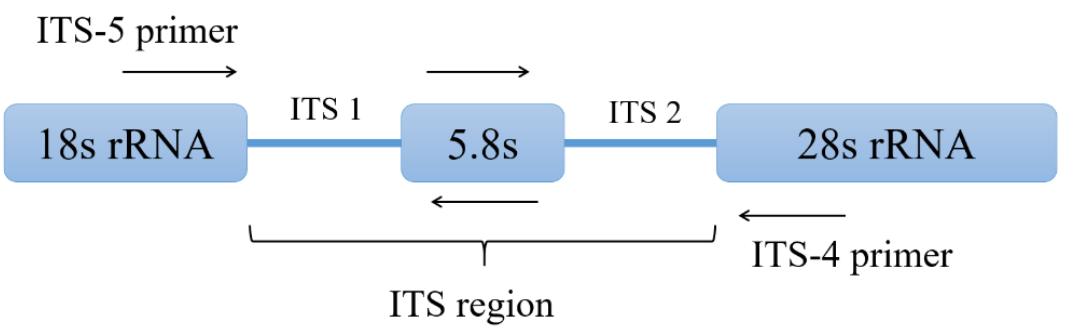

Figure 1. Diagram of nuclear ribosomal RNA (nrRNA) gene containing ITS1, 5.8S, and ITS2 regions with primer binding sites

Table 2. List of ITS sequences of Myzus persicae samples used in this study, length and GenBank accession numbers

\begin{tabular}{c|c|c|c|c}
\hline Species & $\begin{array}{c}\mathbf{C O}_{2} \text { level } \\
(\mathbf{p p m})\end{array}$ & Name of the sample & $\begin{array}{c}\text { Length } \\
(\mathbf{b p})\end{array}$ & Accession no \\
\hline Myzus persicae & 400 & Sample 1 & 698 & MW581037 \\
M. persicae & 400 & Sample 2 & 699 & MW581033 \\
M. persicae & 400 & Sample 3 & 699 & MW581028 \\
M. persicae & 400 & Sample 4 & 699 & MW581038 \\
M. persicae & 600 & Sample 1 & 699 & MW581034 \\
M. persicae & 600 & Sample 2 & 699 & MW581035 \\
M. persicae & 600 & Sample 3 & 698 & MW581032 \\
M. persicae & 600 & Sample 4 & 698 & MW581029 \\
M. persicae & 600 & Sample 5 & 699 & MW581031 \\
M. persicae & 800 & Sample 1 & 699 & MW581036 \\
M. persicae & 800 & Sample 2 & 699 & MW581030 \\
M. persicae & 800 & Sample 3 & 698 & MW581039 \\
M. persicae & 800 & Sample 4 & 699 & MW581073 \\
M. persicae & 1000 & Sample 1 & 699 & MW581070 \\
M. persicae & 1000 & Sample 2 & 698 & MW581071 \\
M. persicae & 1000 & Sample 3 & 699 & MW581072 \\
M. persicae & 1000 & Sample 4 & 699 & MW581069 \\
\hline
\end{tabular}

\section{Bioinformatic analysis}

The ITS sequences of aphid samples were initially edited manually than aligned using CLC Main Workbench Version 6.2 (CLC bio, Denmark) software. To determine the intraspecific variation among the seventeen $M$. persicae samples grown in four different levels of $\mathrm{CO}_{2}$, we constructed a phylogenetic tree using ITS sequences obtained in this study. Intraspecific pairwise alignments of all loci considered (ITS1, 5.8S, ITS2) in this research were generated using CLC Main Workbench Version 6.2 (CLC bio, Denmark) software for all $M$. persicae samples. The phylogenetic tree was built under the neighbor joining algorithm. The relationships were assessed using 1000 bootstrap replicates.

\section{Secondary structure analyses}

In order to predict the most stable secondary structure of the nuclear ribosomal DNA, containing ITS1, 5.8S and ITS2 sequences, the established full sequences were folded 
and visualized using the mfold structure prediction package of CLC RNA Workbench Version 6.2 (CLC bio, Denmark) software by energy minimizing. Each consensus sequence, belonging to a a particular $\mathrm{CO}_{2}$ level, was folded separately to build the full structure.

\section{In silico virtual RFLP analysis}

Delimitation of the start and end points of each sequence was carefully trimmed manually in order to arrange the nucleotide bases at the start and end of the sequences were identical for all individuals. Computer-simulated (in silico) RFLP analysis of the ITS sequences of all amplified specimens was performed using pDRAW32 (AcaClone Software). The following 17 restriction enzymes which are commonly used in bench digests and identification in silico RFLP analysis for phytoplasmas (Lee et al., 1998; Oksal et al., 2017; Usta et al., 2018) were adapted and screened: AluI, BamHI, BfaI, Bst UI (ThaI), DraI, EcoRI, HaeIII, HhaI, HinfI, HpaI, HpaII, KpnI, Sau3AI (MboI), MseI, RsaI, SspI, and TaqI. Among these enzymes, HaeIII, HpaII and TaqI did not cut any of the sequences submitted to digestion, but were retained in the data set for comparison. Following the in silico restriction digestion, a virtual 1.0\% agarose gel image plotted automatically to the computer screen to capture the RFLP pattern of 16Sr DNA sequences using the program pDRAW32 (AcaClone Software).

\section{Results}

An approximately $700 \mathrm{bp}$ single amplified PCR product was obtained in all $M$. persicae samples for the complete rDNA ITS region. The ITS sequence ranged from $698 \mathrm{bp}$ to $699 \mathrm{bp}$ in all accessions. Only three base difference was detected within the $800 \mathrm{ppm} \mathrm{CO} 2$ level of growing condition of $M$. persicae. The divergence in the ITS genes among the individuals grown at $800 \mathrm{ppm}$ tested was low (c. $0.4 \%$ informative sites) (Figure 2). However, the variation among the individuals within the individual grown at ambient $\mathrm{OC} 2$ (400 ppm and elevated $\mathrm{CO}_{2}$ levels (600 and $1000 \mathrm{ppm}$ ), appears to be very low, with no informative positions. GenBank accession numbers of the ITS sequences and the origin of samples are given in Table 2.

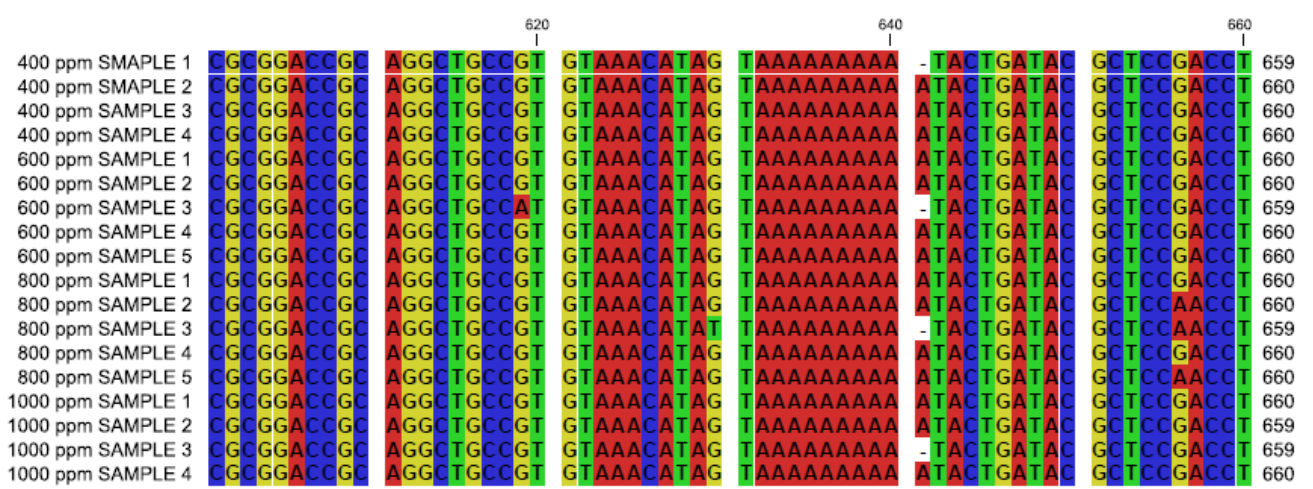

Figure 2. Sequence alignment of ITS region of M. persicae individuals grown at ambiante and elevated $\mathrm{CO}_{2}$ levels. Mutational sites of ITS region of M. persicae grown at $800 \mathrm{ppm} \mathrm{CO}_{2}$ level are boxed 
The intraspecific variation among the individuals of $M$. periscae resolved by ITS sequence comparisons. Our results show that the intraspecific variability on ITS sequence of $M$. persicae was noticeable at $800 \mathrm{ppm}$ level. In comparison to ambient $\mathrm{CO}_{2}, 600 \mathrm{ppm}$ and $1000 \mathrm{ppm} \mathrm{CO}_{2}$ levels, except one specimen, the ITS sequences of a $M$. persica specimens grown at $800 \mathrm{ppm} \mathrm{CO}_{2}$ level was phylogenetically diverse. The green peach aphids grown at $800 \mathrm{ppm}$ are clustered in the same branch (Group I) which clearly distinguished from the other individuals grown under ambient $\mathrm{CO}_{2}$ and 600 and 1000 ppm $\mathrm{CO}_{2}$ levels (Figure 3).

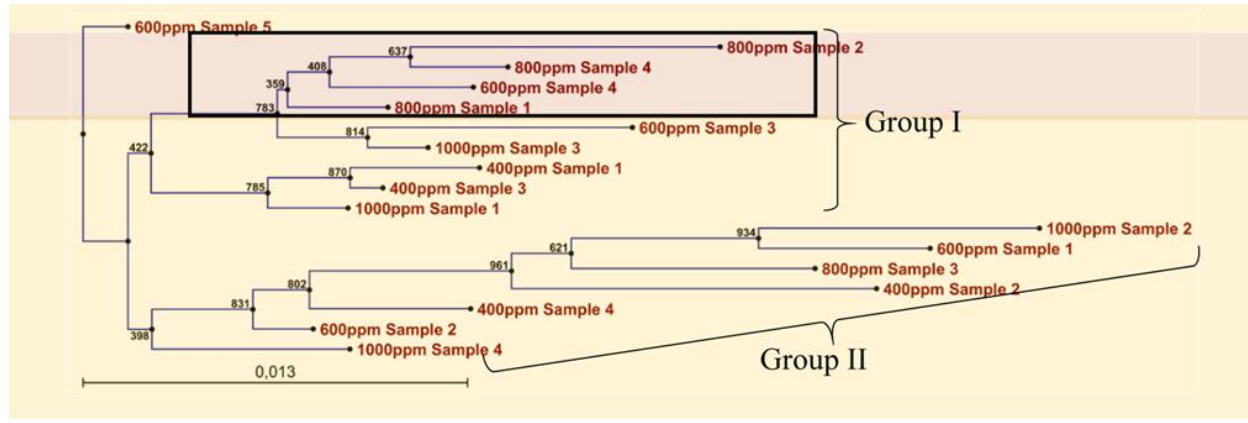

Figure 3. Phylogram generated from ITS nucleotide sequence data of 17 Myzus persicae specimens grown at elevated $\mathrm{CO}_{2}\left(600,800\right.$ and 1000ppm) levels and ambient $\mathrm{CO}_{2}$ level using

the Neighbor Joining algorithm. The value of 1000 was used for bootstrap analysis and corresponding values are shown on individual branches. The green peach aphids grown at 800 ppm $\mathrm{CO}_{2}$ level are boxed

In Figure 3, the neighbor joining phylogram displays the genetic relationships between the aphid samples grown at different $\mathrm{CO}_{2}$ levels. The Group I composed of 2 subgroups. One of the subgroups consists of 3 green peach aphids all from the same chamber of greenhouse having $800 \mathrm{ppm} \mathrm{CO}_{2}$ level, indicating their genetic similarity. This cluster received $78 \%$ support in the bootstrap analysis. The Group I consist also individuals from ambient and other elevated $\mathrm{CO}_{2}$ levels, as do Group II, reflecting intraspecific species similarities. However, an aphid sample from the same origin grown at $600 \mathrm{ppm} \mathrm{CO}_{2}$ level (sample 5) did not grouped together by other aphid samples but instead formed a separate individual branch rooting the tree, indicating its divers feature (Figure 3). In Group II, the entire ITS sequence was typically fully conserved within the species, and the variation observed was negligible. In general, no distinct treatment effects were observed on ITS sequences in elevated $\mathrm{CO}_{2}$ levels among the aphid samples of Group II. Overall results show that the green peach aphid reared on eggplants at different levels of increased atmospheric $\mathrm{CO}_{2}$ showed a low level of intraspecific variation for Group II members.

Along with nucleotide sequences, the most stabile secondary structure of these sequences was also obtained to compare the topology of sequence paring. What is most significant is the strong distinction in the secondary structure pattern of consensus sequence of individuals grown at $800 \mathrm{ppm} \mathrm{CO}_{2}$ level (Figure 4). The most stable secondary structure alone provided a clear and informative secondary structure topology.

The in silico RFLP analyses revealed that the ITS region produced similar banding patterns for all seventeen specimens of $M$. persicae. None of the restriction enzyme used in this study were able to generate different banding patterns (Figure 5). The banding patterns obtained from restriction digestion was not sufficient to differentiate the tested specimens with no informative positions. 

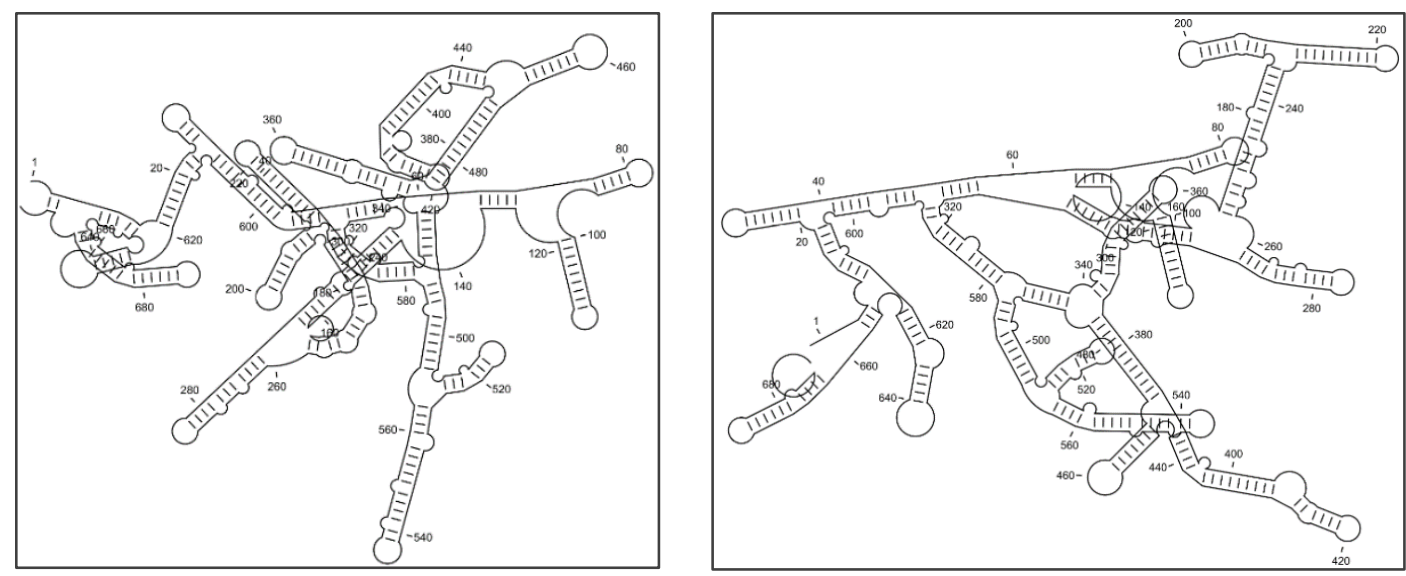

Figure 4. The most stabile secondary structure based on 730 bp of consensus ITS sequence of green peach aphids grown at ambient $\mathrm{CO}_{2}(\mathrm{~A})$ and elevated $(600,800(\mathrm{~B})$ and $1000 \mathrm{ppm}) \mathrm{CO}_{2}$ levels

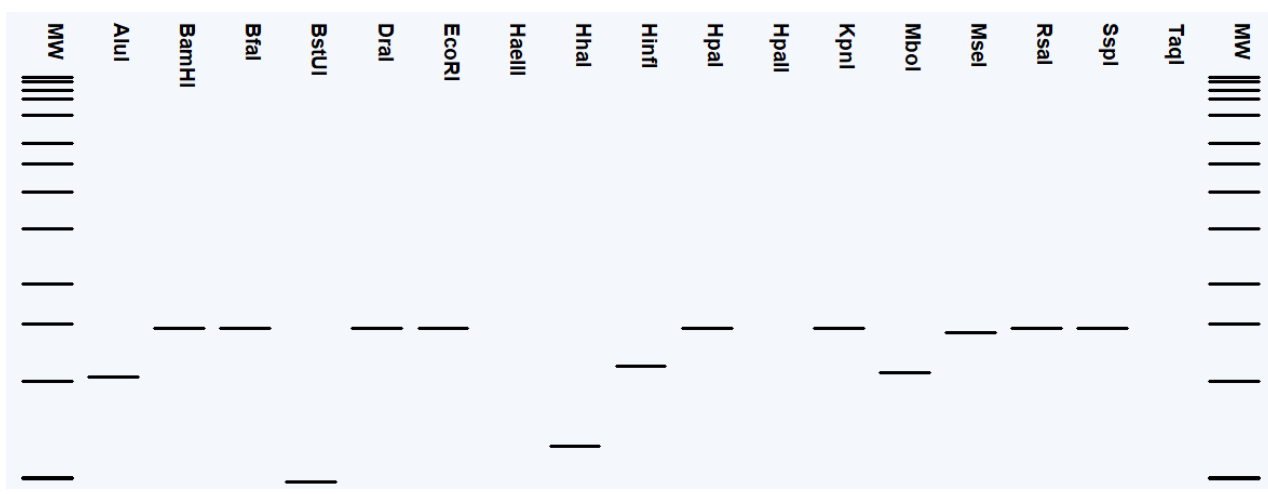

Figure 5. In silico virtual restriction endonuclease digestion profile of ITS sequence of M. persicae grown at $400 \mathrm{ppm} \mathrm{CO}_{2}$ level. In the simulated digestions for the recognition sites 17 restriction enzymes were used. The restriction patterns of the all samples were identical. MW: 1 $\mathrm{kb}$ DNA ladder

\section{Discussion}

The present study was undertaken to investigate the level of intraspecific variation within the rRNA gene sequences of $M$. persicae based on sequence alignment, secondary structure prediction and in silico PCR-RFLP under the $\mathrm{CO}_{2}$ pressure. It is frequently reported that the internal transcribed spacer (ITS) region of nuclear ribosomal DNA (nr DNA) has been widely used for identification and phylogenetic analysis of many microorganism, plant and insect families (Lee et al., 1998; Mir et al., 2009; Keskin et al., 2017; Oksal et al., 2017; Usta et al., 2018).

For comparative purposes, we focused on the prediction of the most stabile secondary structure of ITS sequences and in silico virtual RFLP analysis to our consensus sequences of aphids grown at 400, 600, 800 and 1000 ppm $\mathrm{CO}_{2}$ levels. Point mutations (insertions, deletions or nucleotide substitutions) in ITS sequence of individuals grown at $800 \mathrm{ppm}$ result in a change in secondary structure configuration and fragment size. However, this change did not affect the in silico virtual RFLP profiles of aphids tested in this study. The all ITS sequences used in our study showed identical virtual RFLP patterns indicating 
that all these samples cannot be distinguished by this method. The present data suggest that the in silico virtual RFLP patterns is not sufficient to understand the intraspecific variation within the species and cannot be perceived by a consideration of virtual RFLP pattern alone. For instance, in this study, the in silico approach implementing virtual digestion by 17 key restriction enzymes, did not enabled easy visualization of polymorphisms in ITS sequences of $M$. persicae. However, it may have done for phytoplasma detection and identification and would ultimately facilitate the discovery of new phytoplasma lineages (Lee et al., 1998; Ramdeen and Rampersad, 2012). In species identification and differentiation, recent entomological applications of RFLP studies have focused on mtCOI gene to solve known mitochondrial DNA polymorphism in Coleoptera, Hemiptera, Hymenoptera, and Lepidoptera (Germain et al., 2013; Arimoto and Iwaizumi, 2014; Ovalle et al., 2014; Vesterlund et al., 2014). Comparison of virtual RFLP analysis versus the prediction of secondary structure analysis revealed that the interpretive feature of the later one seems to be higher in understanding of the intraspecific sequence divergence of a given species.

Mutational variation within ITS sequences of $M$. persica specimens grown at $800 \mathrm{ppm}$ $\mathrm{CO}_{2}$ level probably due to the rate of sexual and asexual reproduction, the number of generations annually, the rate of mutation, and the environmental conditions. Coviella and Trumble (1998) emphasize that the extended period of elevated $\mathrm{CO}_{2}$ level seems to be a strong evolutionary force in many insect species, who has relatively short generation times and potential for rapid genetic turnover.

The ITS region of nuclear ribosomal is separated into ITS 1 and ITS 2. The ITS 1 is present between $18 \mathrm{~S}$ and 5.8S rRNA whereas ITS 2 is present between 5.8 and 26s rRNA. 5.8S rRNA is a highly-conserved region (Baldwin et al., 1995). Generally, the M. persicae individual grown in ambient and elevated $\mathrm{CO}_{2}$ levels separated into two groups by phylogenetic analysis of ITS sequences. Except one specimen of $800 \mathrm{ppm} \mathrm{CO}_{2}$, the aphid samples grown at $800 \mathrm{ppm} \mathrm{CO}_{2}$ level were clustered in the same group. This is more likely to be related to an elevated $\mathrm{CO}_{2}$ factor, since some characters are strongly affected by different selection pressures (Mir et al., 2010) and, at some level, expected due to the variable nature of the ITS1 and ITS2 sequences (Nilsson et al., 2009). Here, we used elevated $\mathrm{CO}_{2}$ concentration as selection pressure, however, the data presented above leave little room for interpretation on the actual influence of elevated $\mathrm{CO}_{2}$ on ITS sequences, thus the reason that mutational changes increased elevated $\mathrm{CO}_{2}$ level in this study remain unknown. The present results should be tested with more specimens experimentally. Pillmann et al. (1997) reports that for the measurement of the amount of intraspecific variation within a particular population may not require sampling of many individuals. In the point of view of the conserved nucleotide sequences, long term studies will make critical contribution to our understanding of elevated $\mathrm{CO}_{2}$ effects on sequence divergence within a species.

\section{Conclusion}

Although there are many studies investigating the possible implications of the increasing $\mathrm{CO}_{2}$ level in the Earth's atmosphere on the genetic characteristics of living organisms, the evolutionary affects remain uncertain. We conducted a preliminary study to analyze the possible changes on the green peach aphid ribosomal DNA sequences grown under ambient $\mathrm{CO}_{2}\left(\mathrm{a} \mathrm{CO}_{2}\right)(400 \mathrm{ppm})$, e $\mathrm{CO}_{2}(600 \mathrm{ppm})$, e $\mathrm{CO}_{2}(800 \mathrm{ppm})$ and $\mathrm{CO}_{2}(1000 \mathrm{ppm}) \mathrm{CO}_{2}$ levels. Among the green peach aphid individuals who gave several 
generations after adapting to different $\mathrm{CO}_{2}$ levels $(400 \mathrm{ppm}, 600 \mathrm{ppm}, 800 \mathrm{ppm}$ and $1000 \mathrm{ppm}$ ), striking and exciting differences were found in the ITS region of those who developed at $800 \mathrm{ppm}$ carbon dioxide level. Under the light of these results, it has been seen that elevated atmospheric $\mathrm{CO}_{2}$ levels may have an evolutionary force on $M$. persicae. However, additional studies are needed to test this hypothesis with more aphid samples and high number of offspring. Continued scientific studies are required to determine the relationship between elevated $\mathrm{CO}_{2}$ levels and the evolutionary link.

\section{REFERENCES}

[1] Akyürek, B., Zeybekoğlu, Ü., Görür, G., Karavin, M. (2019): New records for aphid fauna of Turkey from Samsun province. - Munis Entomology \& Zoology 14(2): 383-388.

[2] Arimoto, M., Iwaizumi, R. (2014): Identification of Japanese Lymantria species (Lepidoptera: Lymantriidae) based on PCR-RFLP analysis of mitochondrial DNA. - Applied Entomology and Zoology 49: 159-169.

[3] Baldwin, B. G., Sanderson, M. J., Porter, J. M., Wojciechowski, M. F., Campbell, C. S., Donoghue, M. J. (1995): The ITS region of nuclear ribosomal DNA: A valuable source of evidence on angiosperm phylogeny. - Annals of the Missouri Botanical Garden 82: 247-277.

[4] Blackman, R. L., Eastop, V. F. (2006): Aphids on the world's Herbaceous plants and shrubs. - John wiley and sons, Chichester, 2 volume set, 1460p. ISBN-10: 0-471-48973-5, ISBN-13: 978-0-471-48973-3.

[5] Blackman, R. L., Eastop, V. F. (2020): Aphids of the world's plants: an online identification and information guide. - World Wide Web electronic publication, http://www.aphidsonworldsplants.info (Erişim 07.06.2020).

[6] Bonan, G. B., Doney, S. C. (2018): Climate, ecosystems, and planetary futures: The challenge to predict life in Earth system models. - Science 359: 6375. Available at: https://doi.org/10.1126/science.aam8328, http://science.sciencemag.org/content/359/6375/eaam8328,

[7] Chen, F., Wu, G., Ge, F., Parajulee, M. N., Shrestha, R. B. (2005): Effects of elevated $\mathrm{CO}_{2}$ and transgenic Bt cotton on plant chemistry, performance, and feeding of an insect herbivore, the cotton bollworm. - Entomologia Experimentalis et Applicata 115: 341-350.

[8] Coviella, C. E., Trumble, J. (1998): Effects of elevated atmospheric Carbon Dioxide on Insect-Plant Interactions. - Conservation Biology 13(4): 700-712.

[9] Germain, J.-F., Chatot, C., Meusnier, I., Artige, E., Rasplus, J.-Y., Cruaud, A. (2013): Molecular identification of Epitrix potato flea beetles (Coleoptera: Chrysomelidae) in Europe and North America. - Bulletin of Entomological Research 103: 354-362.

[10] Intergovernmental Panel on Climate Change (IPCC) (2014): Climate change 2014: Synthesis report. - Pachauri, R. K., Meyer, L. (eds.) Retrieved from https://www.ipcc.ch/site/assets/uploads/2018/05/ SYR_AR5_FINAL_full_wcover.pdf.

[11] Keskin, F., Kaya, I., Usta, M., Demir, I., Sipahioglu, H. M., Nem, Y. (2017): Molecular Cloning and Sequence Analysis of the its Region of Nuclear Ribosomal DNA for Species Identification in Dodders (Cuscuta; Convolvulaceae). - International Journal of Agriculture \& Biology ISSN Print: 1560-8530; ISSN Online: 1814-9596 17-0384/2017/19-6-14471451 DOI: 10.17957/JJAB/15.0442 http://www.fspublishers.org.

[12] Lee, I. M., Gundersen-Rindal, D. E., Davis, R. E., Bartoszyk, I. M. (1998): Revised classification scheme of phytoplasmas based on RFLP analysis of 16S rRNA and ribosomal protein gene sequences. - International Journal of Systematic Bacteriology 48: 1153-1169.

[13] Lodos, N. (1982): Turkey entomology II. (General, practical and faunistic). - Aegean University Publications, No. 429, Izmir, Turkey, 590p.

[14] Mir, A., Kaufman, L., Noor, A., Motazacker, M. M., Jamil, T., Azam, M., Kahrizi, K., Rafiq, M. A., Weksberg, R., Nasr, T., Naeem, F., Tzschach, A., Kuss, A. W., Ishak, G. E., Doherty, 
D., Ropers, H. H., Barkovich, A. J., Najmabadi, H., Ayub, M., Vincent, J. B. (2009): Identification of mutations in TRAPPC9, which encodes the NIK- and IKK-beta-binding protein, in nonsyndromic autosomal-recessive mental retardation. - Am J Hum Genet 85: 909-915.

[15] Mir, B. A., Koul, S., Kumar, A., Kaul, M. K., Raina, S. N. (2010): Intraspecific variation in internal transcribed spacer (ITS) regions of rDNA in Withania somnifare (Linn.) DunalApplications. - Indian Journal of Biotechnology 9: 325-328.

[16] Nieto Nafria, J. M., Andreev, A. V., Binazzi, A., Mier Durante, M. P., Perez Hidalgo, N., Rakauskas, R., Stekolshchikov, A. (2013): Fauna Europaea: Aphidoidea. - Fauna Europaea version 2.6.2. Available from: http://www.faunaeur.org (accessed June 07, 2020).

[17] Nilsson, R. H., Ryberg, M., Abarenkov, K., Sjökvist, E., Kristiansson, E. (2009): The ITS region as a target for characterization offungal communities using emerging sequencing technologies. - FEMS Microbiology Letters 296(1): 97-101.

Doi: 10.1111/j.1574-6968.2009.01618.

[18] Oksal, H. D., Kaya, A. F., Oksal, E., Tursun, N., Sipahioglu, H. M. (2017): Detection and Molecular Characterization of two 'Candidatus Phytoplasma Trifolii' Isolates Infecting Peppers at the Same Ecological Niche. - International Journal of Agriculture Biology 19(6): 1372-1378. Doi: 10.17957/IJAB/15.0420.

[19] Ovalle, T. M., Parsa, S., Hernández, M. P., Becerra Lopez-Lavalle, L. A. (2014): Reliable molecular identification of nine tropical whitefly species. - Ecology and Evolution 4: 37783787.

[20] Özdemir, I. (2020): Some new records on aphid (Hemiptera, Aphididae) fauna of Turkey and aphid-host plant interactions. - Journal of the Entomological Research Society 22(2): 191201. ISSN 13020250.

[21] Pillmann, A., Woolcott, G. W., Olsen, J. L., Stam, W. T., King, R. J. (1997): Inter and intraspecific genetic variation in Caulerpa (Chlorophyta) based on nuclear rDNA ITS sequences. - European Journal of Phycology 32: 379-386.

[22] Pollard, D. G. (1973): Plant penetration by feeding aphids (Hemiptera: Aphidoidea): a review. - Bulletin of Entomological Research 62: 631-714.

[23] Ramdeen, S., Rampersad, S. N. (2012): Intraspecific Differentiation of Colletotrichum gloeosporioides sensu lato Based on In Silico Multilocus PCR-RFLP Fingerprinting. - Mol Biotechnol 53(2): 170-181.

[24] Sharma, U., Sharma, S. K., Sanjta, S. (2016): Association and Utilization of Bio-Agents In Management of Aphid Insect-Pests. - International Journal of Advanced Research 4(9): 2135-2139. Doi:10.21474/IJAR01/1699.

[25] Stiling, P., Cattell, M., Moon, D. C., Rossi, A., Hungate, B. A., Hymus, G., Drake, B. (2002): Elevated atmospheric $\mathrm{CO}_{2}$ lowers herbivore abundance but increases leaf abscission rates. Global Change Biology 8(7): 658-667. https://doi.org/10.1046/j.1365-2486.2002.00501.x.

[26] Sudderth, E. A., Sudderth, E. B. (2014): Quantifying aphid behavioral responses to environmental change. - Entomologia Experimentalis et Applicata 150(1): 7-18. https://doi.org/10.1111/eea.12139.

[27] Usta, M., Guller, A., Sipahioglu, H. M. (2018): Molecular analysis of Candidatus Phytoplasma trifolii and Candidatus Phytoplasma solani associated with phytoplasma diseases of tomato (PDT) in Turkey. - Int. J. Agric. Biol. 20: 1991-1996.

[28] Van Emden, H., Harrington, R. (2017): Aphids as crop pests. $2^{\text {nd }}$ ed. - CABI North American Office, Cambridge, Massachusetts, 686p.

[29] Vesterlund, S. R., Sorvari, J., Vasemägi, A. (2014): Molecular identification of cryptic bumblebee species from degraded samples using PCR-RFLP approach. - Mol. Ecol. Resour. 14: 122-126.

[30] White, T. J., Bruns, T., Lee, S., Taylor, J. (1990): Amplification and direct sequencing of fungal ribosomal RNA genes for phylogenetics. - PCR Protocols: A Guide to Methods and Applications. 